Artykuly / Articles

\author{
Agnieszka Lapińska \\ ORCID: 0000-0003-2110-4688 \\ agnieszkalapinska84@wp.pl \\ Uniwersytet Przyrodniczo-Humanistyczny w Siedlach \\ Wydział Nauk Społecznych
}

\title{
Policja w działaniach antyterrorystycznych
}

\author{
Police in anti-terrorist operations
}

DOI: 10.34739/doc.2020.17.02

\begin{abstract}
Abstrakt: Artykuł jest poświęcony funkcjonowaniu Policji w systemie bezpieczeństwa państwa w kontekście zagrożenia terroryzmem. Opisuje podstawowe zadania tej grupy dyspozycyjnej w zakresie zapobiegania, przeciwdziałania i neutralizowania skutków działań o charakterze terrorystycznym. Analizie podlega także zakres uprawnień ustawowych Policji w związu $z$ wejściem w życie $z$ dniem 2 lipca 2016 r. tzw. ustawy antyterrorystycznej.
\end{abstract}

Słowa kluczowe: Policja, terroryzm, antyterroryzm, kontrterroryzm, grupy dyspozycyjne

Abstract: The article is devoted to the functioning of the Police in the context of the terrorist threats. It describes the basic tasks of this dispositional group in prevention, counteraction and neutralization the effects of the activities of a terrorist nature. The analysis includes statutory powers of the Police in connection with the new Anti-Terror Law and issues related to this legislation.

Keywords: Police, terrorism, antiterrorism, counterterrorism, dispositional groups

\section{Wstęp}

Terroryzm jako zagrożenie nie jest zjawiskiem nowym w historii świata. Wielkie przewroty polityczne i wojskowe, upadki mocarstw i rządów wiązały się $z$ działaniami pewnych zorganizowanych grup, które dziś moglibyśmy określać jako terrorystyczne. Na początku XX w. chociażby polskie akcje niepodległościowe na terenie Cesar- 
stwa Rosyjskiego, w tym też z udziałem Józefa Piłsudskiego, uznawano za przejawy terroryzmu ${ }^{1}$. Przez wieki zmieniały się za to metody stosowane przez terrorystów, różne też są intencje i zamiary stojące za czynami terrorystycznymi (religijne, niepodległościowe, separatystyczne, polityczne, ekonomiczne i inne). Wreszcie, ocena działań danej osoby lub grupy jako działania terrorystyczne albo walka w słusznej sprawie jest względna (vide casus Piłsudskiego). W zależności od przypadku można oceniać daną osobę bądź jako terrorystę, bądź jako bojownika o wolność ${ }^{2}$. $Z$ tego między innymi powodu nie ma jednolitej definicji terroryzmu, bowiem wiele zależy od kontekstu politycznego lub historycznego danego zdarzenia.

Współcześnie niemal każdy dzień przynosi nowe doniesienia medialne o dokonanych atakach terrorystycznych, próbach ataku lub o zdemaskowanych przygotowaniach ataków w różnych częściach świata zarówno w krajach rozwiniętych, jak i biedniejszych częściach globu. W polityce i mediach rozpowszechnione jest także pojęcie terroryzmu międzynarodowego, a więc takiego, którego cele nie koncentruja się na jednym kraju lub regionie. Wykraczaja one poza te granice, na przykład poprzez działania terrorystów skierowane przeciwko cudzoziemcom lub zagranicznym celom albo zaprogramowane na wpływanie na politykę obcego rządu3 ${ }^{3}$. Problem zagrożenia terrorystycznego nie jest zatem problemem wewnętrznym danego państwa lub organizacji, odczuwany jest w znacznie szerszej skali.

Przypadki tragicznych w skutkach zamachów terrorystycznych w Europie Zachodniej (Francja, Belgia, Niemcy), zaistniałe w latach 2015-2016 powoduja wzrost poziomu zagrożenia terrorystycznego w całej Unii Europejskiej, w tym również w Polsce. Pomimo iż Polska nie była dotąd obiektem bezpośredniego ataku terrorystycznego, zagrożenie to pozostaje całkiem realne, mając na względzie geopolityczną pozycję kraju (członkostwo w NATO, UE, udział w dotychczasowych misjach międzynarodowej koalicji antyterrorystycznej po

1 W. Lada, Polscy terroryści, Kraków 2014, s. 19 i n.

2 S. Serwiak, Cyberprzestrzeń jako źródło zagrożenia terroryzmem, [w:] Przestępczość zorganizowana. Swiadek koronny. Terroryzm w ujęciu praktycznym, red. E. Pływaczewski, Kraków 2005, s. 590.

3 A. Pawłowski, Typologia terroryzmu politycznego, [w:] Terroryzm polityczny, red. J. Muszyński, Warszawa 1991, s. 34-35. 
11 września 2001 r.) oraz taki czynnik, jak „tranzytowe” położenie (z krajów byłego ZSRR, Bliskiego Wschodu i Azji Środkowowschodniej do Europy Zachodniej).

Zabezpieczeniu kraju przed zagrożeniami terrorystycznymi służy szereg instrumentów, począwszy od odpowiednich regulacji prawnych po wypracowane mechanizmy współpracy służb i instytucji czuwajacych nad bezpieczeństwem oraz podmiotów cywilnych i zwykłych obywateli. Wzorem innych krajów sojuszniczych także w Polsce wprowadzane sa szczególne uprawnienia dla służb strzegacych bezpieczeństwa publicznego, ukierunkowane na usprawnienie zapobiegania, zwalczania i niwelowania skutków terroryzmu. Szczegółowe zapisy prawne przyznające służbom, organom i instytucjom określone kompetencje w zakresie działań antyterrorystycznych, wynikaja co do zasady $z$ ustaw regulujacych funkcjonowanie danej służby. Ponadto celom takim służyć ma między innymi poszerzenie uprawnień ABW, Policji i innych służb, wprowadzone ustawa $z$ dnia 10 czerwca 2016 r. o działaniach antyterrorystycznych ${ }^{4}$ (dalej jako: ustawa o AT). Regulacja ta jest o tyle istotna, iż w naszym systemie prawnym uprzednio nie istniał jeden akt prawny, który ujmowałby tę problematykę kompleksowo.

\section{Rola Policji w działaniach antyterrorystycznych}

W systemie bezpieczeństwa antyterrorystycznego państwa, jak i w przypadku każdego innego rodzaju zagrożenia o charakterze powszechnym, jedna $z$ podstawowych formacji służących ochronie bezpieczeństwa ludzi oraz do utrzymywania bezpieczeństwa i porządku publicznego jest Policja5. Jako paramilitarna grupa dyspozycyjna, posiadajaca wyspecjalizowany i specyficzny charakter, Policja ukierunkowana jest na podejmowanie działań na rzecz ochrony bezpieczeństwa obywateli oraz ich mienia 6 . W kręgu kompetencji Policji pozostaje zatem działanie przeciw zagrożeniu działaniami terrorystycznymi oraz obowiazek przeciwdziałania innym stanom

\footnotetext{
4 Ustawa z dnia 10 czerwca 2016 r. o działaniach antyterrorystycznych, Dz.U. 2016, poz. 904.

5 Ustawa z dnia 6 kwietnia 1990 r. o Policji, Dz.U. 2015, poz. 355 z późn. zm., art.1, ust.1.

6 J. Maciejewski, Grupy dyspozycyjne. Analiza socjologiczna, Wrocław 2012, s. 40.
} 
zagrożenia bezpieczeństwa publicznego, w których moga ujawniać się działania terrorystów.

Do chwili wejścia w życie ustawy o AT terroryzm na polskim gruncie prawnym był co do zasady postrzegany przez pryzmat prawa karnego. Według definicji przyjętej w Kodeksie karnym (od 2004 r.) za przestępstwo o charakterze terrorystycznym uznaje się czyn zabroniony, zagrożony kara pozbawienia wolności, której górna granica wynosi co najmniej 5 lat, popełniony w celu poważnego zastraszenia wielu osób, zmuszenia organu władzy publicznej Rzeczypospolitej Polskiej lub innego państwa albo organu organizacji międzynarodowej do podjęcia lub zaniechania określonych czynności, a także wywołanie poważnych zakłóceń w ustroju lub gospodarce Rzeczypospolitej Polskiej, innego państwa lub organizacji międzynarodowej, a także groźbę popełnienia takiego czynu7. Kodeks karny w dalszej części penalizuje przestępstwa polegające na zakładaniu, kierowaniu oraz udziale w zorganizowanej grupie albo zwiazku majacym na celu popełnienie przestępstwa o charakterze terrorystycznym (art. $258 \S$ 2 i 4 k.k.), finansowaniu przestępstw o charakterze terrorystycznym (art. 165a k.k.), rozpowszechnianiu lub publicznym prezentowaniu treści mogących ułatwić popełnienie przestępstwa o charakterze terrorystycznym (art. 255a k.k.), przekroczenia granicy w celu popełnienia przestępstwa o charakterze terrorystycznym (art. 259a k.k.). Kodeks ustanawia także obostrzenia w wymiarze kary w sytuacji skazania za przestępstwo o charakterze terrorystycznym (art. 65 ust. 1 k.k.) oraz poddaje pod polska jurysdykcję cudzoziemców popełniajacych za granica przestępstwo o charakterze terrorystycznym (art. 110 ust. 1 k.k.).

Niezależnie od powyższych za przestępstwo o charakterze terrorystycznym może być uznane każde inne przestępstwo - zabójstwo, porwanie, branie zakładników, kradzież, spowodowanie katastrofy w ruchu lądowym czy też cyberprzestępstwa (ataki hakerskie) i inne. Mając na względzie różnorodność metod podejmowanych przez potencjalnych terrorystów, katalog przestępstw jest nieograniczony. Jak wskazuje Cezariusz Sońta: „Terrorysta nie jest w stanie

7 Ustawa z dnia 6 czerwca 1997 r. Kodeks karny, Dz.U. 2018, poz. 1600, art. 115 $\S 20$. 
dokonać tzw. aktu terrorystycznego, który nie byłby zachowaniem kryminalizowanym w przepisach polskiego prawa karnego"8.

Powiazane regulacje zawarte sa także - w zakresie zapobiegania i penalizowania finansowaniu terroryzmu - w ustawie $z$ dnia 16 listopada 2000 r. o przeciwdziałaniu praniu pieniędzy oraz finansowaniu terroryzmu ${ }^{9}$ oraz przepisach regulujących stany nadzwyczajne (stan wojenny ${ }^{10}$, stan wyjatkowy ${ }^{11}$ ) oraz zarzadzanie kryzysowe ${ }^{12}$. Zagrożenie zewnętrzne państwa, spowodowane działaniami o charakterze terrorystycznym, może być podstawą ogłoszenia stanu wojennego, zaś szczególne zagrożenie konstytucyjnego ustroju państwa, bezpieczeństwa obywateli lub porządku publicznego, spowodowane działaniami o charakterze terrorystycznym - ogłoszenia stanu wyjątkowego. W zakresie kompetencji organów zarządzania kryzysowego pozostaje także zapobieganie i usuwanie skutków zdarzeń o charakterze terrorystycznym, a więc takich sytuacji, które sa skutkiem przestępstwa o charakterze terrorystycznym w rozumieniu art. $115 \S 20$ k.k. ${ }^{13}$ lub stanowią zagrożenie wystąpienia takiego czynu, powodując sytuację kryzysowa. Ustawodawca, mając na względzie, iż często celami ataków terrorystycznych są obiekty infrastruktury krytycznej, wprowadził pewne zapisy w ustawach dotyczacych funkcjonowania portów lotniczych, żeglugi, elektrowni itp. W każdym przypadku ustawy szczególne, w tym i pragmatyki funkcjonowania służb, precyzowane sa treścią aktów wykonawczych (rozporządzeń odpowiednich ministrów, zarządzeniami KGP) o różnym stopniu jawności.

Przeciwdziałanie aktom terroryzmu oraz udział w działaniach kontrterrorystycznych należą do podstawowych ustawowych funkcji

8 C. Sońta, Przestepstwo o charakterze terrorystycznym $w$ prawie polskim, „Wojskowy Przegląd Prawniczy" 2005, nr 4.

9 Dz.U. 2016, poz. 299 z późn. zm., przyp.: ustawa została uchylona i zastapiona ustawa $z$ dnia 1 marca 2018 r. o przeciwdziałaniu praniu pieniędzy oraz finansowaniu terroryzmu (Dz.U. 2018, poz. 723).

10 Ustawa $z$ dnia 29 sierpnia 2002 r. o stanie wojennym oraz o kompetencjach Naczelnego Dowódcy Sił Zbrojnych i zasadach jego podległości konstytucyjnym organom Rzeczypospolitej Polskiej, Dz.U. 2017, poz. 1932, art. 2 ust. 1.

11 Ustawa $z$ dnia 21 czerwca 2002 r. o stanie wyjątkowym, Dz.U. 2017, poz. 1928, art. 2 ust. 1 .

12 Ustawa z dnia 26 kwietnia 2007 r. o zarzązaniu kryzysowym, Dz.U. 2018, poz. 1401.

13 Ibidem, art. 3, pkt 11. 
Policji14. Jakkolwiek wiodacca rola w rozpoznaniu i zapobieganiu aktom terroru na terenie Polski przyznana została Agencji Bezpieczeństwa Wewnętrznego, to m.in. działania Policji stanowia podstawę wykrycia tego rodzaju przestępstw oraz fundament do skutecznego reagowania. Innymi słowy Policja jako grupa dyspozycyjna o najszerszym ze służb zakresie działania, ogólnokrajowym zasięgu, dysponująca zasobami ludzkimi i narzędziami technologicznymi jest nie tylko wsparciem dla innych służb, ale także bezpośrednim wykonawca działań, bez których nie byłoby możliwe skuteczne przeciwstawienie się aktom terrorystycznym.

Rola Policji w ramach tych działań sprowadza się do dwóch głównych segmentów: zapobiegania i zwalczania zagrożenia terroryzmem oraz zwalczania i niwelowania skutków już zaistniałego ataku terrorystycznego. Pierwszy $z$ wymienionych segmentów obejmuje przede wszystkim dwa rodzaje działania.

1. Prowadzenie czynności operacyjno-rozpoznawczych, w tym rozpoznanie operacyjne dotyczace obywateli polskich, cudzoziemców oraz grup, organizacji i zwiazków, co do których zachodzi podejrzenie działalności o charakterze terrorystycznym, uczestniczenie w grupach, organizacjach lub zwiazkach podejrzewanych o działalność terrorystyczną lub jej wspieranie, finansowanie takiej działalności w kraju czy poza jego granicami, pozyskiwanie poufnych osobowych źródeł informacji wywodzących się $z$ wcześniej wymienionych struktur przestępczych. Ciężar wykonania tego rodzaju zadań spoczywa przede wszystkim na funkcjonariuszach pionu kryminalnego oraz pionu prewencji.

2. Czynności porzadkowo-ochronne, obejmujące m.in. dokonywanie aktualnej analizy zagrożeń rejonów i obiektów, ze szczególnym uwzględnieniem miejsc potencjalnie narażonych na ataki (w tym placówek dyplomatycznych), zabezpieczenie miejsc przebywania dużej liczby ludności (dworce kolejowe, autobusowe i inne obiekty komunikacji, centra handlowe, rejony urzędów administracji publicznej, imprez masowych itp.), zabezpieczenie obiektów infrastruktury krytycznej, współpraca $z$ podmiotami cywilnymi w zakresie zabezpieczenia

14 Ustawa $z$ dnia 6 kwietnia 1990 r. o Policji..., art. 3 ust. 2 pkt 3 i 3a. 
(np. ochrona lotniska), ochrona prewencyjna niektórych osób i obiektów, kontrola bezpieczeństwa środków transportu samolotów, pasażerów, bagażu w komunikacji lotniczej krajowej i międzynarodowej ${ }^{15}$.

W przypadku wystapienia zdarzenia o charakterze terrorystycznym Policja:

- dokonuje fizycznego zwalczania terroryzmu;

- zapewnia natychmiastowe, w trybie alarmowym, skierowanie do interwencji zespołów minersko-pirotechnicznych, oddziału prewencji i negocjatorów policyjnych;

- mobilizuje pododdziały antyterrorystyczne poprzez zwiększenie liczby policjantów pełniących dyżury domowe i przeprowadzenie szkoleń w zakresie alarmowego uruchamiania tych pododdziałów;

- dokonuje niezbędnych uzgodnień $z$ organami pozapolicyjnymi oraz zapewnia sprawny obieg informacji o zagrożeniach i zdarzeniach w systemie funkcjonowania służb dyżurnych podległych jednostek, utrzymuje ścisłą wymianę informacji o zagrożeniach $z$ innymi służbami, uzgadnia wspólne działania w ramach wojewódzkich i powiatowych (miejskich) zespołów reagowania kryzysowego celem zapewnienia ochrony wytypowanych obiektów infrastruktury (ujęć wody, stacji przekaźnikowych, urządzeń energetycznych i telekomunikacyjnych, miejsc składowania substancji niebezpiecznych itp.);

- zbiera informacje na temat miejsca zdarzenia (specyfika terenu, trasy dojazdu i odjazdu, infrastruktura mediów miejskich: wodociagi, energetyka, gazownictwo) i wyznacza miejsca koncentracji sił odwodu oraz przysłanych $z$ innych jednostek (siły prewencyjne);

- zabezpiecza miejsce zdarzenia, przeprowadza ewakuacje ludności, zabezpiecza drogi dojazdu, pilotuje pojazdy służb medycznych i ratowniczych itp.;

15 Ustawa $z$ dnia 26 kwietnia 2007 r. o zarzadzaniu... 
- dokonuje zatrzymania lub zneutralizowania sprawców zdarzenia, zabezpiecza materiał dowodowy i prowadzi postępowanie przygotowawcze ${ }^{16}$.

Wskazane czynności należa tylko do części działań podejmowanych przez Policję w sytuacji kryzysowej. Policja od 2011 r. w zakresie zagrożeń związanych $z$ zarządzeniem kryzysowym przyjęła znormalizowany system alarmowy NATO (powielony w ustawie antyterrorystycznej), toteż na chwilę obecna posiada wypracowane procedury działania na wypadek zagrożenia, precyzowane aktami wewnętrznymi.

W skład Policji, obok m.in. służby kryminalnej, prewencyjnej oraz organizacyjnej, wchodzą także wyodrębnione oddziały prewencji i pododdziały antyterrorystyczne ${ }^{17}$. W strukturze organizacyjnej Policji oraz innych organów bezpieczeństwa wyróżnić można m.in. następujące wyspecjalizowane jednostki:

- Biuro Operacji Antyterrorystycznych Komendy Głównej Policji, którego zadaniem jest przeciwdziałanie terroryzmowi i jego fizyczne zwalczanie oraz organizowanie, koordynowanie i nadzorowanie działań Policji w tym zakresie ${ }^{18}$. BOA KGP reprezentuje polskie służby i bierze udział w działaniach tzw. grupy ATLAS - formy współpracy państw unijnych, w skład której wchodzi 35 specjalnych jednostek policyjnych z 27 państw Unii Europejskiej, powołanych do fizycznego zwalczania terroryzmu. Podobna forma współpracy służb funkcjonująca na forum Europolu nosi nazwę BOA;

- Centralne Biuro Śledcze Komendy Głównej Policji, którego zadaniem jest m.in. rozpoznawanie operacyjne przestępczości o charakterze terrorystycznym;

- Główny Sztab Policji Komendy Głównej Policji, który odpowiada za zabezpieczenie imprez masowych i nadzór nad bezpieczeństwem obiektów infrastruktury krytycznej;

16 Uchwała nr 252 Rady Ministrów z dnia 9 grudnia 2014 r. w sprawie „Narodowego Programu Antyterrorystycznego na lata 2015-2019”, „Monitor Polski” 2014, poz. 1218.

17 Ustawa $z$ dnia 6 kwietnia 1990 r. o Policji..., art. 4 ust. 3 pkt 2.

18 Centralny Pododdział Kontrterrorystyczny Policji „BOA”, https://policja.pl/pol/ boa, (data dostępu: 31.12.2020). 
- jednostki prewencji - na poziomie lokalnym i krajowym, które odpowiadają za edukację społeczna na rzecz przeciwdziałania przestępczości, w tym zagrożeniom o charakterze terrorystycznym;

- Centrum Antyterrorystyczne Agencji Bezpieczeństwa Wewnętrznego (CAT), które jest jednostką koordynacyjno-analityczna w zakresie przeciwdziałania terroryzmowi i jego zwalczania. Służbę w nim pełnia, poza funkcjonariuszami ABW, także oddelegowani funkcjonariusze, żołnierze i pracownicy m.in. Policji, Straży Granicznej, Biura Ochrony Rządu, Agencji Wywiadu, Służby Wywiadu Wojskowego, Służby Kontrwywiadu Wojskowego oraz Służby Celnej19:

- Samodzielne Pododdziały Kontrterrorystyczne Policji20, podległe bezpośrednio Komendantowi Głównemu Policji, pomimo ich strategicznego rozmieszczenia w 10 największych miastach Polski przeznaczone do reagowania na terenie całego kraju.

W ramach wykonywanych działań Policja współpracuje $z$ Państwową Strażą Pożarną, Agencją Bezpieczeństwa Wewnętrznego, Agencją Wywiadu Wojskowego i Służbą Kontrwywiadu Wojskowego, Żandarmerią Wojskowa, Strażą Graniczną, Europolem i Interpolem, Biurem Ochrony Rzadu, Ministerstwem Zdrowia oraz służbami innych państw i organizacji międzynarodowych w ramach współdziałania i współpracy transgranicznej. Współpraca ta obejmuje także podmioty cywilne w zależności od charakteru zdarzenia.

\section{Szczególne obowiązki i uprawnienia Policji w świetle uregulowań ustawy o działaniach antyterrorystycznych}

Wspomniano już, iż ustawa o AT w sposób kompleksowy porządkuje i precyzuje sposób działania i zakres kompetencji służb na

\footnotetext{
19 A. Makarski, Centrum Antyterrorystyczne Agencji Bezpieczeństwa Wewnętrznego. Geneza, zasady działania oraz doświadczenia po pierwszym roku funkcjonowania, http:/ /www.abw.gov.pl/pl/zadania/zwalczanie-terroryzmu/centrum-antyterrorysty/62,Centrum-Antyterrorystyczne-CAT.html, (data dostępu: 3.08.2016).

20 Zarządzenie nr 26 Komendanta Głównego Policji z dnia 16 kwietnia 2019 r. $\mathrm{w}$ sprawie metod i form działania pododdziałów kontrterrorystycznych Policji, Dz. Urz. 2019, poz. 161 i 125.
} 
wypadek wystapienia działań terrorystycznych zagrażających państwu. Wprowadza ona powszechnie obowiazujacy i dostosowany do standardów NATO czterostopniowy system stopni alarmowych (tzw. CRP) na wypadek zagrożeń terrorystycznych oraz stopni alarmowych w cyberprzestrzeni ${ }^{21}$. Przyjęty system stopni alarmowych powiazany jest $z$ systemem udzielania $\mathrm{w}$ trybie pilnym niezbędnego Policji wsparcia ze strony Sił Zbrojnych RP w przypadku, jeśli siły i środki Policji okażą się niewystarczające do reagowania w przypadku zamachu (podobne zapisy o subsydiarnym wsparciu udzielanym Policji zawarto w znowelizowanych przepisach dotyczacych Żandarmerii Wojskowej i Straży Granicznej). Regulacja ta jest analogiczna do zapisów dotyczacych stanów nadzwyczajnych. Podobieństwem jest też fakt, iż Oddziały Sił Zbrojnych RP użyte do pomocy oddziałom Policji pozostaja w systemie dowodzenia Sił Zbrojnych RP. Przepisy te koreluja $z$ zapisami ustawy o Policji, które także przewiduja, iż w razie zagrożenia bezpieczeństwa publicznego lub zakłócenia porządku publicznego (w tym zdarzenia o charakterze terrorystycznym), o ile środki Policji okażą się niewystarczające, udzielona może być pomoc ze strony oddziałów i pododdziałów Sił Zbrojnych ${ }^{22}$.

Ustalono cztery stopnie alarmowe, w zależności od skali zagrożenia atakiem terrorystycznym ${ }^{23}$.

Pierwszy stopień (stopień ALFA24), wprowadzany w przypadku uzyskania informacji o możliwości wystapienia zdarzenia o charakterze terrorystycznym, którego rodzaj i zakres jest trudny do przewidzenia.

Drugi stopień (stopień BRAVO), wprowadzany w przypadku zaistnienia zwiększonego i przewidywalnego zagrożenia wystapieniem zdarzenia o charakterze terrorystycznym, którego konkretny cel zdarzenia nie został zidentyfikowany.

Trzeci stopień (stopień CHARLIE), wprowadzany w przypadku:

21 Uprzednio obowiąujące Zarządzenie nr 18 Prezesa Rady Ministrów z dnia 2 marca 2016 r. w sprawie wykazu przedsięwzięć i procedur systemu zarządzania kryzysowego, bazujace na systemie stopni alarmowych NATO obejmowało wyłącznie administrację rządową.

22 Ustawa $z$ dnia 6 kwietnia 1990 r. o Policji..., art. 18.

23 Ustawa $z$ dnia 10 czerwca 2016 r. o działaniach..., art. 15 ust. 1.

24 Według alfabetu NATO. 
a) wystapienia zdarzenia potwierdzajacego cel potencjalnego zdarzenia o charakterze terrorystycznym godzacego $\mathrm{w}$ bezpieczeństwo lub porządek publiczny albo bezpieczeństwo Rzeczypospolitej Polskiej albo bezpieczeństwo innego państwa lub organizacji międzynarodowej oraz stwarzającego potencjalne zagrożenie dla Rzeczypospolitej Polskiej;

b) uzyskania wiarygodnych i potwierdzonych informacji o planowanym zdarzeniu o charakterze terrorystycznym na terytorium Rzeczypospolitej Polskiej;

c) uzyskania wiarygodnych i potwierdzonych informacji o planowanym zdarzeniu o charakterze terrorystycznym, którego skutki moga dotyczyć obywateli polskich przebywajacych za granica lub instytucji polskich albo polskiej infrastruktury, mieszczących się poza granicami Rzeczypospolitej Polskiej.

Czwarty stopień (stopień DELTA), wprowadzany w przypadku:

a) wystapienia zdarzenia o charakterze terrorystycznym, powodującego zagrożenie bezpieczeństwa lub porządku publicznego albo bezpieczeństwa Rzeczypospolitej Polskiej albo bezpieczeństwa innego państwa lub organizacji międzynarodowej oraz stwarzającego zagrożenie dla Rzeczypospolitej Polskiej;

b) gdy uzyskane informacje wskazują na zaawansowaną fazę przygotowań do zdarzenia o charakterze terrorystycznym na terytorium Rzeczypospolitej Polskiej;

c) gdy uzyskane informacje wskazuja na zaawansowana fazę przygotowań do zdarzenia o charakterze terrorystycznym, które ma być wymierzone w obywateli polskich przebywających za granica lub instytucje polskie albo polska infrastrukturę mieszczace się poza granicami Rzeczypospolitej Polskiej, a zebrane informacje wskazuja jednocześnie na nieuchronność takiego zdarzenia ${ }^{25}$.

Novum wprowadzone ustawą o AT jest także podział działań na działania ściśle antyterrorystyczne, definiowane jako „działania organów administracji publicznej polegające na zapobieganiu zdarzeniom o charakterze terrorystycznym, przygotowaniu do przejmo-

25 Ustawa $z$ dnia 10 czerwca 2016 r. o działaniach..., art. 15 ust. 1. 
wania nad nimi kontroli w drodze zaplanowanych przedsięwzięć, reagowaniu w przypadku wystapienia takich zdarzeń oraz usuwaniu ich skutków, w tym odtwarzaniu zasobów przeznaczonych do reagowania na nie" 26 . Ponadto działania kontrterrorystyczne, rozumiane jak „działania wobec sprawców, osób przygotowujących lub pomagajaccych w dokonaniu przestępstwa o charakterze terrorystycznym, o którym mowa w art. $115 \S 20$ k.k., prowadzone w celu wyeliminowania bezpośredniego zagrożenia życia, zdrowia lub wolności osób lub mienia przy wykorzystaniu"27.

Ustawa przewiduje, iż wiodąca rolę w procesie zapobiegania terroryzmowi pełni Szef Agencji Bezpieczeństwa Wewnętrznego, któremu powierzono instrumenty prawno-organizacyjne, umożliwiajace skuteczną realizację ww. zadania. Odpowiedzialność w zakresie kontroli nad zdarzeniami o charakterze terrorystycznym poprzez działania strategiczne, planowanie, reagowanie w przypadku wystapienia takich zdarzeń oraz usuwanie ich skutków, w tym odtwarzanie zasobów wykorzystywanych do reagowania na te zdarzenia, spoczywa na ministrze do spraw wewnętrznych. Głównym jednak wykonawca działań z zakresu AT pozostaje Szef ABW. Stąd też Policja jest mu podległa w takich obszarach, jak:

- koordynacja czynności analityczno-informacyjnych podejmowanych przez służby specjalne oraz wymiana informacji przekazywanych przez Policję, Straż Graniczną, Biuro Ochrony Rządu, Państwową Straż Pożarną, Służbę Celną, Generalnego Inspektora Informacji Finansowej, Generalnego Inspektora Kontroli Skarbowej, Żandarmerię Wojskową i Rządowe Centrum Bezpieczeństwa, dotyczacych zagrożeń o charakterze terrorystycznym oraz danych o osobach mogacych mieć zwiazek ze zdarzeniami o charakterze terrorystycznym ${ }^{28}$;

- uzyskiwanie od Szefa ABW danych z prowadzonego przezeń wykazu osób mogacych mieć zwiąek ze zdarzeniami o charakterze terrorystycznym ${ }^{29}$;

\footnotetext{
26 Ibidem, art. 2 pkt 1.

27 Ibidem, art. 2 pkt 2.

28 Ibidem, art. 5 ust. 1.

29 Ibidem, art. 6 ust. 1 i ust. 2 pkt. 1.
} 
- koordynacja czynności operacyjno-rozpoznawczych podejmowanych przez służby specjalne oraz przez Policję i inne służby, tj. czynności obserwowania i rejestrowania, przy użyciu środków technicznych, obrazu zdarzeń w miejscach publicznych oraz dźwięku towarzyszącego tym zdarzeniom podejmowanych przez funkcjonariuszy celnych, w tym wydawania zaleceń, mających na celu usunięcie lub minimalizację zaistniałego zagrożenia terrorystycznego 30 ;

- obowiazek przekazywania Szefowi ABW nieodpłatnie dostępu do danych i informacji zgromadzonych w rejestrach publicznych i ewidencjach, a także obrazu zdarzeń rejestrowanego przez urządzenia rejestrujące obraz umieszczone w obiektach użyteczności publicznej, przy drogach publicznych i innych miejscach publicznych oraz otrzymywania nieopłatnie kopii zarejestrowanego zapisu tego obrazu ${ }^{31}$;

- wykonywanie zaleceń Szefa ABW - w uzgodnieniu $z$ ministrem właściwym do spraw wewnętrznych, dotyczących szczególnego zabezpieczenia poszczególnych obiektów - w przypadku wprowadzenia drugiego lub wyższego stopnia alarmowego ${ }^{32}$.

Do realizacji powyższych celów służy także, funkcjonująca już od lat, praktyka delegowania do pracy lub służby w Agencji Bezpieczeństwa Wewnętrznego pracowników lub funkcjonariuszy Policji oraz innych służb33.

Ustawa przewiduje również udział przedstawicieli Policji w tzw. sztabie koordynacyjnym, tworzonym przez Szefa ABW. W przypadku wprowadzenia stopnia alarmowego, odnoszacego się do terytorium RP lub stopnia alarmowego CRP, tworzy się sztab koordynacyjny składający się $z$ wyznaczonych przedstawicieli Prezydenta RP, Prezesa Rady Ministrów, ministra właściwego do spraw wewnętrznych, Ministra Obrony Narodowej, ministra właściwego do spraw zagranicznych, ministra - Koordynatora Służb Specjalnych, jeśli został powołany, a także przedstawicieli służb specjalnych, Policji, Straży Granicznej, Biura Ochrony Rządu, Państwowej Straży

\footnotetext{
30 Ibidem, art. 8 ust. 1 pkt 1.

31 Ibidem, art. 11 pkt. 1 a.

32 Ibidem, art. 12 ust. 1 i 2.

33 Ibidem, art. 14 ust. 1.
} 
Pożarnej, Służby Celnej, Generalnego Inspektora Informacji Finansowej, Generalnego Inspektora Kontroli Skarbowej, Żandarmerii Wojskowej i Rządowego Centrum Bezpieczeństwa oraz inne osoby powołane przez szefa ABW 34 .

O ile pozytywnie $\mathrm{w}$ ocenie opinii publicznej przyjmowane sa racje ustawodawcy $\mathrm{w}$ zakresie potrzeby uporzadkowania kompetencji poszczególnych organów i ustanowienia hierarchii w zakresie działań antyterrorystycznych, to dość kontrowersyjne wydaja się zapisy mówiące o nowych uprawnieniach służb, w tym również Policji. Według opinii wyrażonej w 2016 r., przez Komendanta Głównego Policji Jarosława Szymczyka, „to sa dobre rozwiąania. Mam świadomość, że budzą kontrowersje, bo gdzieś po raz kolejny wkraczamy w sferę uprawnień i wolności każdego człowieka. W dzisiejszych czasach, przy takim poziomie zagrożenia terrorystycznego, $z$ jakim mamy do czynienia w Europie, musimy - i tutaj nie ma innej drogi - kosztem pewnego ograniczenia swobód obywatelskich dać kompetencje służbom do zapewnienia bezpieczeństwa. (...) Jestem pewien, że Polacy doskonale to rozumieją. Żyjemy w czasach, w których to bezpieczeństwo jest wartościa nadrzędna. Jestem przekonany o tym, że mamy tak wypracowane mechanizmy kontrolne, które nie pozwolą nam na nadużywanie tych uprawnien" 35 . Samoświadomość obowiąku skutecznego, ale zgodnego $z$ prawem postępowania jest o tyle istotna, iż to na Policji ciaży obowiazek bezpośredniego reagowania na zdarzenia terrorystyczne w ich początkowej fazie.

Kierujacym działaniami antyterrorystycznymi - w sensie praktycznym, wykonawczym - podejmowanymi przez właściwe służby lub organy w ramach ich ustawowych zadań na miejscu zdarzenia o charakterze terrorystycznym jest funkcjonariusz Policji, wyznaczony przez Komendanta Głównego Policji, a w przypadkach niecierpiących zwłoki przez właściwego miejscowo komendanta wojewódzkiego Policji ${ }^{36}$. Jedynie w drodze wyjątku, w przypadku zdarzenia mającego miejsce na obszarach lub w obiektach należących

\footnotetext{
34 Ibidem, art. 15 ust. 1.

35 Szef policji o ustawie antyterrorystycznej: to sa dobre rozwiazania, http://www.tvn24.pl/wiadomosci-z-kraju,3/policja-kgp-o-projekcie-ustawy-antyterrorystycznej,638137.html, (data dostępu: 01.08.2016).

36 Ustawa $z$ dnia 10 czerwca 2016 r. o działaniach..., art. 18 pkt 1 .
} 
do komórek i jednostek organizacyjnych podległych bezpośrednio lub pośrednio Ministrowi Obrony Narodowej, jest to żołnierz Żandarmerii Wojskowej wyznaczony przez Ministra Obrony Narodowej, a w przypadkach niecierpiących zwłoki przez Komendanta Głównego Żandarmerii Wojskowej.

Nowe uprawnienia służb obejmuja przede wszystkim podejmowanie działań zapobiegawczych i operacyjnych przed zaistnieniem jakiegokolwiek zdarzenia o charakterze terrorystycznym. Funkcjonariusze ABW, Policji i Straży Granicznej zyskuja szersze uprawnienia do pobierania obrazu linii papilarnych lub utrwalania wizerunku twarzy osoby niebędącej obywatelem RP w uzasadnionych, określonych w ustawie, przypadkach ${ }^{37}$. Dane te mają być przekazywane do Komendanta Głównego Policji oraz włączane do baz danych Policji, przy zapewnieniu możliwości dostępu do tych danych ABW, Policji i Straży Granicznej oraz ich przetwarzania i aktualizacji przez te służby na potrzeby prowadzonych przez nie postępowań. Na obecnym etapie kompetencje te pozostaja „uśpione” $z$ uwagi na konieczność wydania stosownego rozporządzenia przez Prezesa Rady Ministrów odnośnie procedury pobierania i przetwarzania tych danych.

Szczegółowe uprawnienia kierującego działaniami antyterrorystycznymi obejmuja, o ile jest to uzasadnione sytuacja i tylko $\mathrm{w}$ niezbędnym zakresie i czasie, następujace działania:

- zarządzenie ewakuacji osób lub mienia $z$ miejsca zdarzenia do wskazanego miejsca, obiektu lub obszaru;

- wprowadzenie zakazu przebywania osób postronnych w miejscu zdarzenia i w jego pobliżu;

- zarządzenie wstrzymania ruchu drogowego lub kolejowego, a także kursowania środków publicznego transportu zbiorowego w miejscu zdarzenia i jego otoczeniu;

- żądanie nieodpłatnego korzystania $z$ nieruchomości lub nieodpłatnego przejęcia do używania ruchomości, w tym środków transportu, a także przedmiotów i urządzeń, koniecznych do przeprowadzenia działań kontrterrorystycznych;

37 Ibidem, art. 10 ust. 1. 
- żądanie udzielenia pomocy od instytucji, organizacji, przedsiębiorców i osób fizycznych lub wydawanie im poleceń (wiążących) ${ }^{38}$.

Ponadto, w przypadku trzeciego lub czwartego stopnia alarmowego, minister właściwy do spraw wewnętrznych, $z$ inicjatywy własnej albo na wniosek Szefa ABW lub Komendanta Głównego Policji, może zarządzić zakaz odbywania zgromadzeń publicznych lub imprez masowych na obszarze lub w obiekcie objętym stopniem alarmowym, jeżeli jest to konieczne dla ochrony życia i zdrowia ludzi lub bezpieczeństwa publicznego ${ }^{39}$.

Kolejnym nowym szczególnym uprawnieniem, przysługujacym m.in. funkcjonariuszom Policji bioracym udział w działaniach antyterrorystycznych, jest możliwość „specjalnego użycia broni”, co oznacza dopuszczalność użycia broni palnej przeciwko osobie dokonującej zamachu, którego skutkiem może być śmierć lub bezpośrednie zagrożenie życia lub zdrowia tej osoby, o ile jest to niezbędne do przeciwdziałania bezpośredniemu, bezprawnemu, gwałtownemu zamachowi na życie lub zdrowie człowieka, a użycie broni palnej w sposób wyrządzający możliwie najmniejszą szkodę jest niewystarczajace i przeciwdziałanie takiemu zamachowi w inny sposób nie jest możliwe, $z$ uwzględnieniem wszelkich okoliczności zdarzenia o charakterze terrorystycznym oraz możliwości działań kontrterrorystycznych ${ }^{40}$. Decyzję (co do wyrażenia zgody oraz cofnięcia zezwolenia) w tym zakresie może podjać kierujący działaniami; wykonawcami są funkcjonariusze Policji, Straży Granicznej, Agencji Bezpieczeństwa Wewnętrznego, żołnierze Żandarmerii Wojskowej lub żołnierze Sił Zbrojnych Rzeczypospolitej Polskiej, wchodzacy w skład tzw. "grupy kontrterrorystycznej”. Specjalne użycie broni podlega zasadom określonym w ustawie $z$ dnia 24 maja 2013 r. ośrodkach przymusu bezpośredniego i broni palnej41.

Ustawa antyterrorystyczna wprowadziła także daleko idace zmiany $\mathrm{w}$ zakresie uprawnień funkcjonariuszy $\mathrm{w}$ postępowaniu przygotowawczym. W przypadku podejrzenia lub usiłowania

\footnotetext{
38 Ibidem, art. 20 ust. 1 i 2.

39 Ibidem, art. 21.

40 Ibidem, art. 23.

41 Ustawa z dnia 24 maja 2013 r. o środkach przymusu bezpośredniego i broni palnej, Dz.U. 2013, poz. 628.
} 
popełnienia albo przygotowania przestępstwa o charakterze terrorystycznym, w celu wykrycia lub zatrzymania albo przymusowego doprowadzenia osoby podejrzewanej, a także w celu znalezienia rzeczy mogacych stanowić dowód $\mathrm{w}$ sprawie lub podlegajacych zajęciu w postępowaniu karnym, prokurator (nie sąd) może postanowić o przeprowadzeniu przez organy ścigania, w tym Policję, przeszukania pomieszczeń i innych miejsc znajdujących się na wskazanym w postanowieniu obszarze lub zatrzymaniu osoby podejrzewanej - jeżeli istnieja uzasadnione podstawy do przypuszczenia, że osoba podejrzewana lub wymienione rzeczy na tym obszarze się znajdują̨2.

Ustawa antyterrorystyczna stanowi pewne novum w polskim porządku prawnym. $Z$ jednej strony spełnia oczekiwania co do zapewnienia porzadku publicznego i bezpieczeństwa na wypadek ataku terrorystycznego, $z$ drugiej stanowi daleko idąca ingerencję w wolności obywatelskie (kwestionowana jest konstytucyjność niektórych rozwiazań). Podnosi się także w opinii publicznej, iż w sytuacji, gdy Polska nie była dotąd dotknięta atakami terrorystycznymi, podobnymi do tragedii zachodnioeuropejskich, brak jest uzasadnienia dla powiększania uprawnień służb. Trudno jest jednak przewidzieć, kiedy i w jaki sposób dane państwo może być narażone na zagrożenia międzynarodowego czy nawet rodzimego terroryzmu, o czym świadcza zamachy dokonane w 2011 r. przez Andersa Breivika w uważanej za ostoję spokoju Norwegii43. Zapewnieniu bezpieczeństwa państwa w obliczu nieprzewidywalnych zagrożeń służyć zatem powinny szczególne regulacje, umożliwiające wdrożenie szczególnych procedur.

\section{Zakończenie}

Współczesne zagrożenie terroryzmem ma charakter nieprzewidywalny, nagły i wielowymiarowy. Zakres stosowanych środków, metod i narzędzi wykorzystywanych przez terrorystów jest tak zróżnicowany i zmienny, iż wymusza to na organach odpowiedzialnych za bezpieczeństwo państwa i obywateli ciagła gotowość i zachowanie

42 Ibidem, art. 25 ust. 1.

43 Cf. E. Czykwin, Anders Breivik. Między duma a wstydem, Warszawa 2019. 
czujności. Zmusza także do budowania sieci wzajemnych powiazań i współpracy pomiędzy jednostkami mundurowymi, organami państwa oraz podmiotami cywilnymi.

Służba, która „stoi na pierwszej linii frontu” oraz w najpowszechniejszym zakresie odpowiada za zabezpieczenie kontrterrorystyczne kraju jest Policja. Pełni ona w działaniach antyterrorystycznych bądź funkcje wspierające i wykonawcze (rolę wiodacca sprawuje szef ABW), bądź samodzielne (jako kierujaccy działaniami) i wtedy może być, na zasadzie subsydiarności, wspierana przez inne służby, takie jak oddziały i pododdziały Sił Zbrojnych, Straży Granicznej i Żandarmerii Wojskowej. Równie istotne jest zatem przygotowanie i utrzymywanie gotowości Policji do realizacji zadań kontrterrorystycznych na poziomie taktycznym, jak i wykonywanie zadań polegających na prowadzeniu działań bojowych na rzecz innych służb i podmiotów pozapolicyjnych.

Regulacje wprowadzone ustawa antyterrorystyczna podtrzymują to kluczowe status quo Policji, pomimo formalnego podporząkowania działań antyterrorystycznych prowadzonych przez służby przewodniej roli Szefa ABW. Policja nawet w nowym rozkładzie sił pozostaje instytucja, która zobowiazana jest do aktywnego działania jako pierwsza (pozycja kierujacego działaniami AT), uczestniczy w całym procesie zwalczania, zapobiegania i niwelowania skutków zdarzeń o charakterze terrorystycznym oraz zobligowana jest do zebrania dowodów i doprowadzenia sprawców przestępstwa przed organy sprawiedliwości.

\section{Bibliografia / References}

\section{Literatura przedmiotu}

Czykwin E., Anders Breivik. Między duma a wstydem, Warszawa 2019. Lada W., Polscy terroryści, Kraków 2014.

Maciejewski J., Grupy dyspozycyjne. Analiza socjologiczna, Wrocław 2012.

Pawłowski A., Typologia terroryzmu politycznego, [w:] Terroryzm polityczny, red. J. Muszyński, Warszawa 1991. 
Serwiak S., Cyberprzestrzeń jako źródło zagrożenia terroryzmem, [w:] Przestępczość zorganizowana. Świadek koronny. Terroryzm w ujęciu praktycznym, red. E. Pływaczewski, Kraków 2005.

Sońta C., Przestępstwo o charakterze terrorystycznym w prawie polskim, „Wojskowy Przegląd Prawniczy” 2005, nr 4.

\section{Akty prawne}

Ustawa $z$ dnia 6 kwietnia 1990 r. o Policji, Dz.U. 2019, poz. 161.

Ustawa $z$ dnia 6 czerwca 1997 r. Kodeks karny, Dz.U. 2018, poz. 1600. Ustawa $z$ dnia 16 listopada 2000 r. o przeciwdziałaniu praniu pieniędzy oraz finansowaniu terroryzmu, Dz.U. 2016, poz. 299 z późn. zm.

Ustawa $z$ dnia 29 sierpnia 2002 r. o stanie wojennym oraz o kompetencjach Naczelnego Dowódcy Sił Zbrojnych i zasadach jego podległości konstytucyjnym organom Rzeczypospolitej Polskiej, Dz.U. 2017, poz. 1932.

Ustawa $z$ dnia 21 czerwca 2002 r. o stanie wyjątkowym, Dz.U. 2017, poz. 1928.

Ustawa $z$ dnia 26 kwietnia 2007 r. o zarządzaniu kryzysowym, Dz.U. 2018, poz. 1401.

Ustawa $z$ dnia 24 maja 2013 r. o środkach przymusu bezpośredniego i broni palnej, Dz.U. 2013, poz. 628.

Ustawa $z$ dnia 10 czerwca 2016 r. o działaniach antyterrorystycznych, Dz.U. 2018, poz. 452.

Ustawa $z$ dnia 1 marca 2018 r. o przeciwdziałaniu praniu pieniędzy oraz finansowaniu terroryzmu, Dz.U. 2018, poz. 723.

Uchwała nr 252 Rady Ministrów z dnia 9 grudnia 2014 r. w sprawie "Narodowego Programu Antyterrorystycznego na lata 2015-2019”, M.P. 2014, poz. 1218.

Uzasadnienie do rządowego projektu ustawy o działaniach antyterrorystycznych oraz o zmianie niektórych innych ustaw (druk sejmowy nr 516), http://www.sejm.gov.pl/Sejm8.nsf/PrzebiegProc. xsp?id=6371C2D58BC29DC2C1257FB5004BBF79, (data dostępu: 31.12.2020).

Zarządzenie nr 26 Komendanta Głównego Policji z dnia 16 kwietnia 2019 r. w sprawie metod i form działania pododdziałów kontrterrorystycznych Policji, Dz. Urz. 2019, poz. 161 i 125. 


\section{Strony internetowe}

Centralny Pododdziat Kontrterrorystyczny Policji „BOA”, https://policja.pl/pol/boa, (data dostępu: 31.12.2020).

Makarski A., Centrum Antyterrorystyczne Agencji Bezpieczeństwa Wewnętrznego. Geneza, zasady działania oraz doświadczenia po pierwszym roku funkcjonowania, http://www.abw.gov.pl/ $\mathrm{pl} /$ zadania/zwalczanie-terroryzmu/centrum-antyterrorysty/62, Centrum-Antyterrorystyczne-CAT.html, (data dostępu: 03.08.2016). tmw $\backslash$ mtom, Szef policji o ustawie antyterrorystycznej: to sa dobre rozwiazania, http://www.tvn24.pl/wiadomosci-z-kraju,3/ policjakgp-o-projekcie-ustawy-antyterrorystycznej,638137.html, (data dostępu: 01.08.2016). 